\title{
立体用途を考慮した階層別空間利用に関する実態調査研究 RESEARCH AND INVESTIGATION ON SPACE ATTRIBUTE AND SPACE USE ON EACH FLOOR OF BUILDINGS IN TOKYO
}

\author{
王世燁*, 尾島 俊 雄**, 三浦 昌生*** \\ Shih-yeh WANG, Toshio OJIMA and Masao MIURA
} \begin{abstract}
like setting up flight routes of airplanes is absolutely necessary to maintain space for living. basis we made investigation and comparison. inner and outer space), space can be classified into 8 types.

(1) public $\cdot$ over $\cdot$ outer space

(5) private $\cdot$ over $\cdot$ outer space

(2) public $\cdot$ over $\cdot$ inner space

(6) private $\cdot$ over $\cdot$ inner space

(3) public $\cdot$ under $\cdot$ outer space

( 7 ) private $\cdot$ under $\cdot$ outer space

(4) public $\cdot$ under $\cdot$ inner space

(8) private $\cdot$ under $\cdot$ inner space
\end{abstract}

Because of the rise in land prices of big cities in Japan, it has been becoming desperately difficult to Keep up enough space for living. The present idea of a plane planning and management of land use can no more stand for the needs of the time. Three-dimensional management of space

From this point of view, first of all, we classified space attribute and space use, and on its

By dividing space attribute into three items (public and private space, over and under space,

Space use is classified into 5 items from the point of city level (building floor, circulaion, greeneries, waters and void), and it is also classified into 10 items from the point of architectural level (facilities for residence, facilities for service, facilities for business, facilities for medical care, facilities for sleeping accommodaion, facilities for education, facilities for culture, facilities for amusement, facilities for industry and facilities for storage and garage).

Applying the above classification of space attribute and space use, we investigated three areas in Tokyo (Ginza area, Kinshichou area and Saginomiya area). We used $5 \mathrm{~m}$ mesh method in 500 $\mathrm{m} \times 500 \mathrm{~m}$ zone from each area. We revealed the present situation of space use of each floor of buildings, and we made the chart of space attribute and space use of each area.

Keywords : Space attribute, Space use, Each floor.

\section{1.はじめに}

日本の大都市における地価高騰は居住空間の存続を絶 望的状況に追い込んで久しい。東京都心の一部の区では 付置義務住宅を制度化する等の対応を急いでいるが，そ の対策の一つとして，住居に限って容積の大幅な緩和が 検討され，ニューヨークの都心部において地区を限って 指定されている高容積の住宅用途規制区域が注目されて いる。

一方, 高密化が進む東京都心部では, 現在, 法定容積 の総量に対して未利用の容積が多く, 敷地割りの変化等 によってさらに利用を進める余地はあるものの, 土地利 用を平面的に計画し，管理するという現在の考え方では，
時代の要求に対処することはできない。航空機の飛行 ルート設定のような空間の立体的管理を行わない限り, 居住空間の確保は不可能に近い。

本来，土地だけで空間を形成することはできない。そ の時代の技術と建築法制度が建設可能な空間の形態，規 模を決定してきた。一方，民法では，土地所有者の権利 は地表の上下に無限に及ぶとされているため, その時代 の技術によって，空間量の増加が可能になった。增加し た空間量を社会に還元しなければ，人口が集中する巨大 都市の居住の場を確保できない。

一方, 建築物が集積した都市においては価值や寿命の 異なるものの同居・混在がますます進みつつある。都市

\footnotetext{
本研究の一部は平成元年度大会 (九州)において発表した。

* 早稲田大学 研究員 $\cdot$ 工博

** 早稲田大学 教授. 工博

*** 早稲田大学 研究員・工博
}

Researcher of Waseda University, Dr. Eng.

Professor of Waseda University, Dr. Eng.

Researcher of Waseda University, Dr. Eng. 
計画法第 9 条が用途地域を定め, 建築基準法第 48 条が 各用途地域ごとに建築物の用途を制限している。建築基 準法第 48 条の別表第 2 によれば，第 1 種住居専用地域 では比較的厳しい用途制限があるものの, 商業地域では, 逆に，一部の工場と危険物貯蔵処理施設を除いては用途 制限がない。つまり，これらの用途地域では建築物の用 途の混在が進んでおり，空間用途の調査によってこの混 在状況を把握することは，建築家・施設管理者・行政者 が空間・設備・躯体を企画し，管理し，かつ，それらの 機能・価值を評価した上で，更新し，さらに，建築の企 画・管理・更新を行う上で重要である。

また，都心部におけるアーバンコンプレックス計画， 総合設計, 地区計画等の進展により, 階層別空間利用の 問題が重要となっている。

その際の価值判断や目標設定を行うための台帳作成を 目的として, 公・私の区別, 位置, 高さ, 用途, 整備年 度等による空間・設備・躯体のコード化が始められよう としている。

こうした観点から，本論文では，東京都中央区の銀座 地区を中心とした調査から，階層別空間利用の実態を明 らかにするとともに，都心部にあって空間の属性と用途 を立体的に管理するための基礎資料を作成する。

\section{2. 空間の属性と用途の分類}

\section{（1）空間属性の分類}

基本的な空間属性は, 公 /私, 上 $/$, 外 /内の 3 種 類とした。

イ.公/私空間は公空間と私空間に分割される。道路・ 公園といった公空間が，居住・業務・商業施設等の私空 間の機能を支えている。

ロ. 上/下空間は，地表面より上の空間と下の空間に 分割される。都市基盤施設を収容することによって下空 間が上空間の機能を支えている。技術の向上により上空 間だけでなく，下空間の開発が急激に進み，地下利用の あり方が注目されている。

八. 外/内空間は外空間と内空間に分割される。閉鎖 的な空間を内空間と定義しそそれ以外を外空間とすると, 外空間が内空間の機能を支えている。

以上の 3 種の属性から空間は下記の 8 分類となる。括 弧内は，該当する空間の一例である。

1. 公 $\cdot$ 上·外空間 (道路, 公園 $\cdots$...

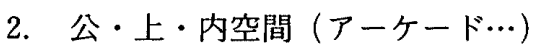

3. 公・下・外空間 (地下のライトコート…)

4. 公・下・内空間 (公共地下歩道 $\cdots$ )

5. 私 $\cdot$ 上. 外空間 $($ 中庭 $\cdots$ )

6. 私 $\cdot$ 上. 内空間 $($ 居室 $\cdots$ )

7. 私・下・外空間 (からぼり …)

8. 私・下・内空間 (地下室 $\cdots$...

上記の分類によって, Fig. 1に示すような空間属性の

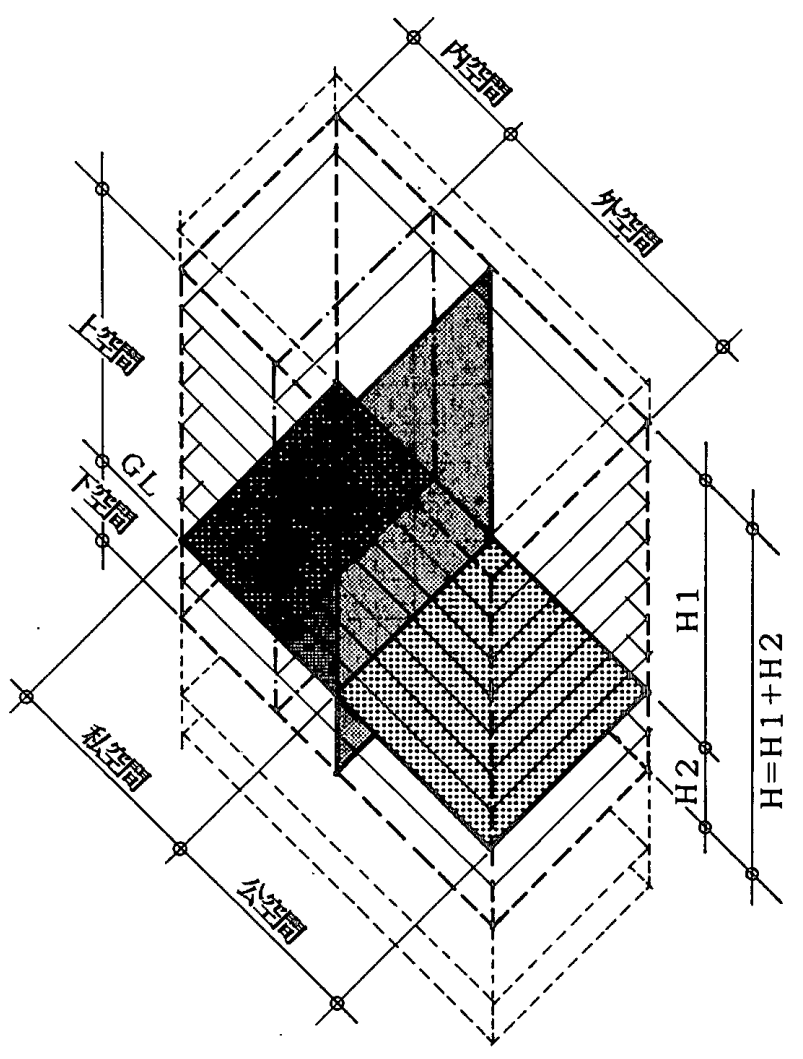

Fig. 1 Classification of space attribute (non-scale)

分類図ができる。地上（H1）の私権を制限することに よって, 採光, 日照, 通風および公共施設の空間や市民 の居住空間が確保されている。また, 今後, 地下 (H2) の私権を一部制限すれば，公共・公益施設を収容する地 下洞道・共同溝等インフラストラクチュアの空間が確保 される。

\section{（2）空間用途の分類}

空間用途を 1 次分類し，これをさらに分類して 2 次分 類とした。空間用途の管理は, 空間用途の 1 次分類項目 を用いる都市レベルの管理と 2 次分類項目を用いる建築 レベルの管理に分けられよう。

空間用途の 1 次分類項目を「建築床」, 「流通」,「緑地」, 「水地」,「void」の 5 項目とする。

「建築休」とは, 建築物の居室, 廊下・階段, これに 付属する機械室等, 人工的に構築された床があって, 人 間が活動できる空間とする。「建築床」については 2 次 分類項目を設け,「住居施設」,「業務施設」,「商業施設」, 「医療施設」, 「宿泊施設」, 「教育施設」, 「文化施設」, 「娱 楽施設」,「工場」,「倉庫・車庫」とする。

「流通」とは，道路，鉄道，供給処理施設等，交通・ 物流のための空間とする。

「緑地」とは，樹木・芝生等の緑が存在する空間およ びそれらが生育可能な裸地の空間とする。道路の街路樹 もこれに含まれる。

「水地」とは, 海面・川面・水路面等, 水面のある空 間とする。 
「void」とは，階別に見て，そ の階のレベルに床がなく吹き抜け ている空間と定義する。例えば, アトリウムの吹き拔け部分がこれ に該当する。通常の道路について は,地表面レベルの空間用途を「流 通」とし，2 階以上のレベルの空 間用途は「void」とする。「緑地」・ 「水地」についても同様とする。

3. 空間属性・用途図の作成

(1) 調查対象地区の設定

17 ポイント法による東京 23 区 部の $500 \mathrm{~m}$ メッシュの中から 1 $\mathrm{km} \times 1 \mathrm{~km}$ のサンプル地区を 17 箇所選定した（Fig. 2)。次に， サンプル地区を構成する計 68
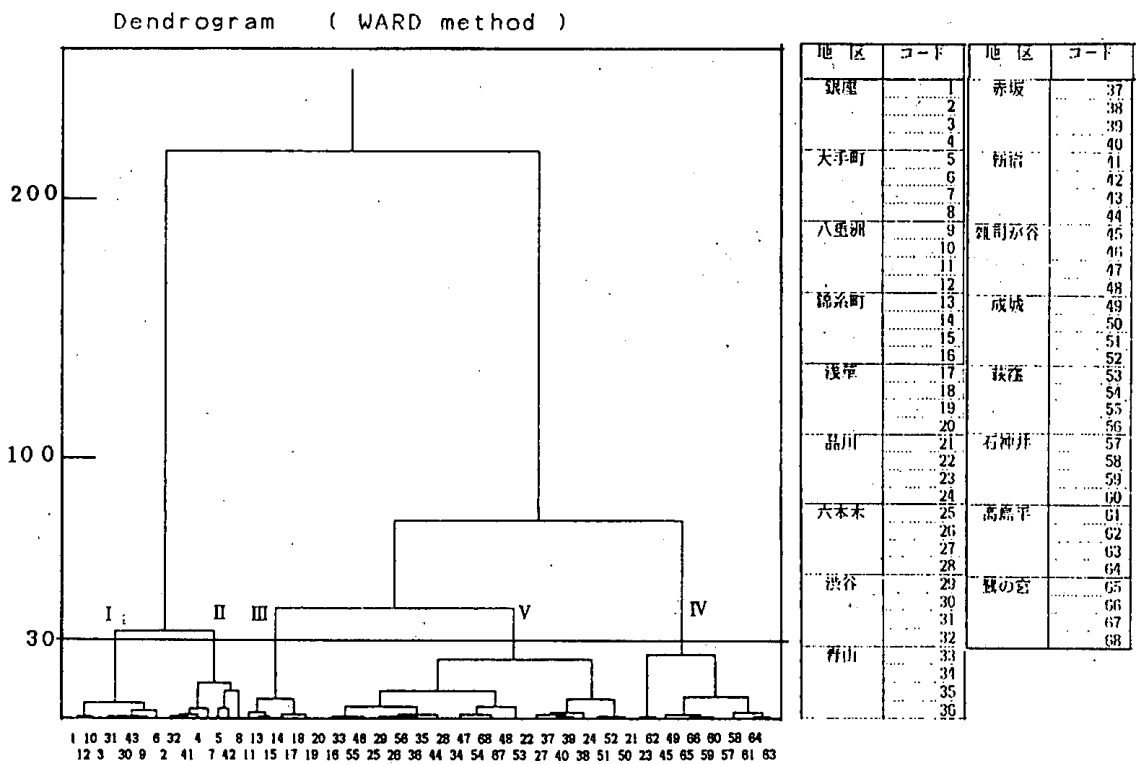

Fig. 3 Treelike chart by cluster analysis

メッシュを対象として, 宅地面積率, ネット容積率, 法 定容積率, 棟数を変量としたクラスター分析を行った。 距離行列に重みうきユークリッド距離を用いたウォード 法によった。これから得られたデンドログラム (Fig. 3) をもとにクラスター数 5 のグルーピングを行い，地区特 性の名称を与えた結果を下記に示す。
$\mathrm{I}$ ·銀座・渋谷・八重洲の商業業務地区
II' 新宿西口・大手町の業務地区
III 錦糸町・浅草の住工・住商混在地区
IV 高島平・光が丘の中高層住宅地区

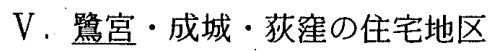

以上, 東京都 23 区内から, 商業業務中心地区として 銀座地区 (中央区)，住工混在地区として錦糸町地区 (墨 田区), 住宅地区として路宮地区（中野区）の 3 地区を 調查対象とした。調查対象地区の平面的広がりをここで

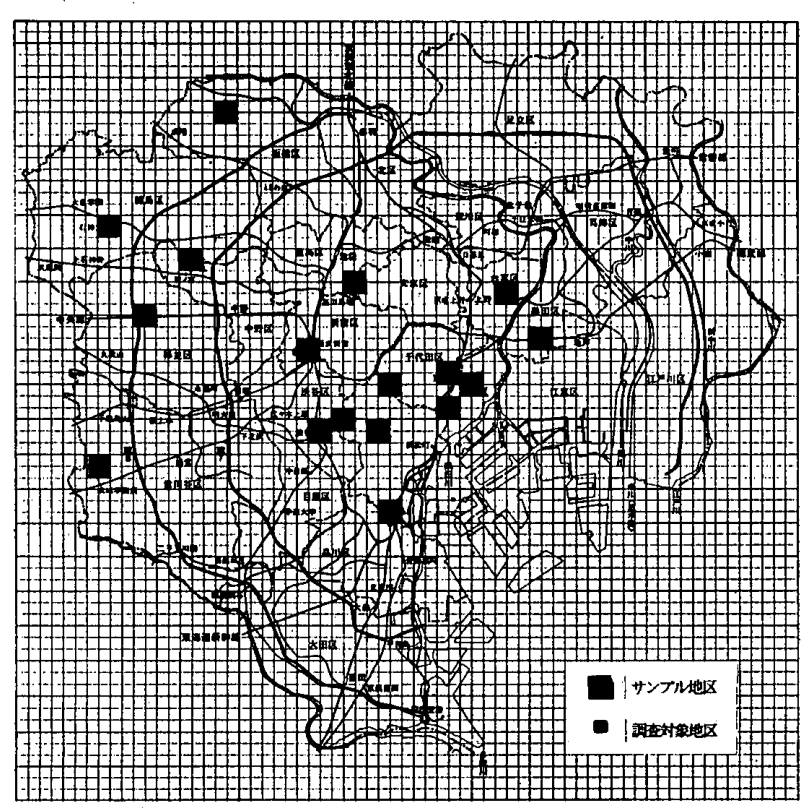

Fig. 2 Sample districe and the investigated areas
は $500 \mathrm{~m} \times 500 \mathrm{~m}$ とし, 17 ポイント法の $500 \mathrm{~m}$ メッシュ から 1 メッシュを選定したが，銀座地区は地区の特性を 明確に把握するために, 17 ポイント法のメッシュ分割 に従わずに調査対象地区を設定した。Fig.4, Fig.5, Fig. 6 に調查対象地区を示す。

これら 3 地区の空間利用に影響を与えている土地利用 規制・建築形態規制について述べると, 銀座地区は全域 が商業地域で, 建ぺい率 $80 \cdot 90 \cdot 100 \%$, 容積率 700 ・ $800 \%$ である。錦糸町地区は商業地域と準工業地域から なり, 前者は建ぺい率 $80 \cdot 90 \cdot 100 \%$, 容積率 $500 \%$, 後者は建ぺい率 $60 \cdot 70 \cdot 80 \%$, 容積率 $300 \%$ である。 鴽宮地区は第 1 種住居専用地域亡近隣商業地域からな り, 前者は建ぺい率 $50 \cdot 60 \%$, 容積率 $100 \cdot 150 \%$, 後 者は建ぺい率 $80 \%$, 容積率 $300 \%$ である。また, 各地 区とも幅員 $12 \mathrm{~m}$ 未満の道路があり，この沿道では前面 道路幅員による容積率制限を受ける。一方, 各地区とも 道路斜線制限と隣地斜線制限を受けるが, 錦系町地区の

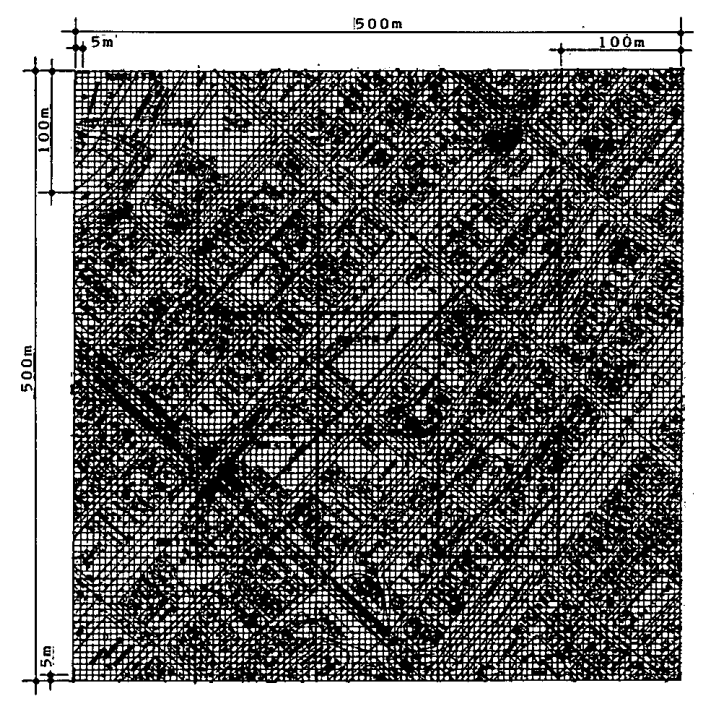

Fig. 4 A investigated area-Ginza area 


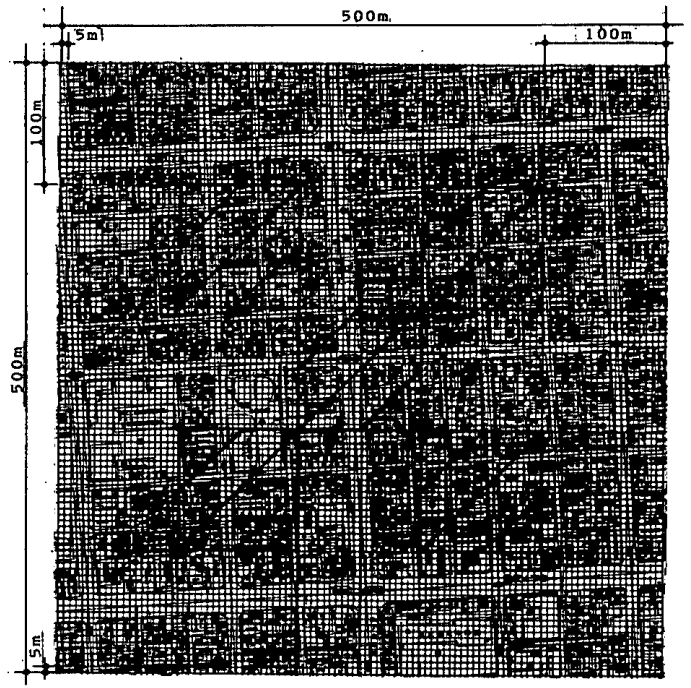

Fig. 5 A investigated area-Kinshichou area

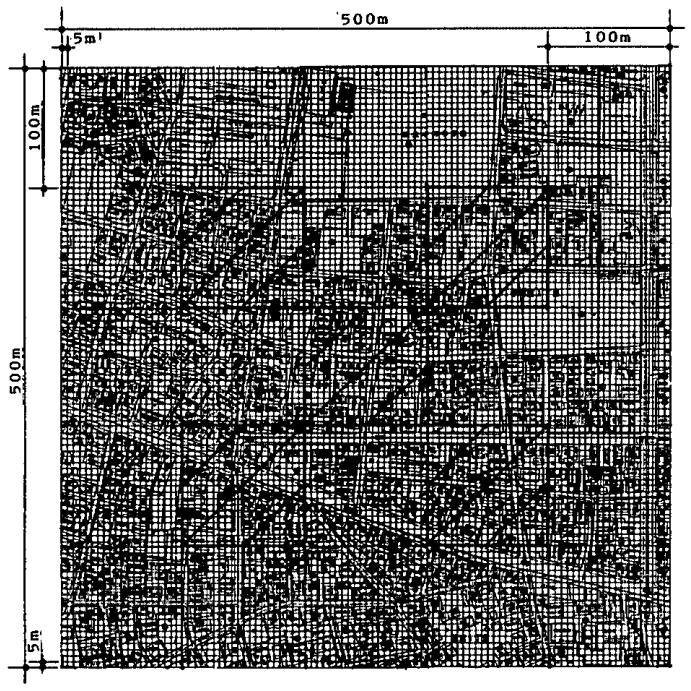

Fig. 6 A investigated area-Saginomiya area

準工業地域では高度地区指定による北側斜線制限を受け る。また，鷺宮地区では全域が高度地区指定による北側 斜線制限と，さらに日影規制を受ける。

(2) メッシュサイズの検討

各調查対象地区を東西・南北方向にメッシュ分割し た。尾島の Space Modular Co-ordination Chart（時空 間分割表)刘によれば，調查対象地区の平面的広がりが $500 \mathrm{~m} \times 500 \mathrm{~m}$ の場合の空間分割は，環境場（Field） $500 \mathrm{~m}$, 原単位 (Mesh) $5 \mathrm{~m}$, 画素 (Pixel) $0.5 \mathrm{~m}$ のS ( 5 ) モデルにあたる。

各調查対象地区を分割するメッシュサイズを $5 \mathrm{~m}$ と 設定するにあたって，メッシュサイズを変化させた場合 の面積の誤差に関する検討を行った。

まず，上記で述べたクラスター数 5 のグルーピングか らそれぞれ 1 地区ずつ選定し，その地区内の $100 \mathrm{~m} \times$ $100 \mathrm{~m}$ エリア 5 箇所 (Fig. 4, Fig.5, Fig. 6 の太線で囲 んだ部分）をサンプルとして、メッシュサイズを $10 \mathrm{~m}$, $5 \mathrm{~m}, 10 / 3 \mathrm{~m}$ と変化させて地表面（1 階）レベルの空間
Table 1 Average rate of errors (\%) in each size of mesh method

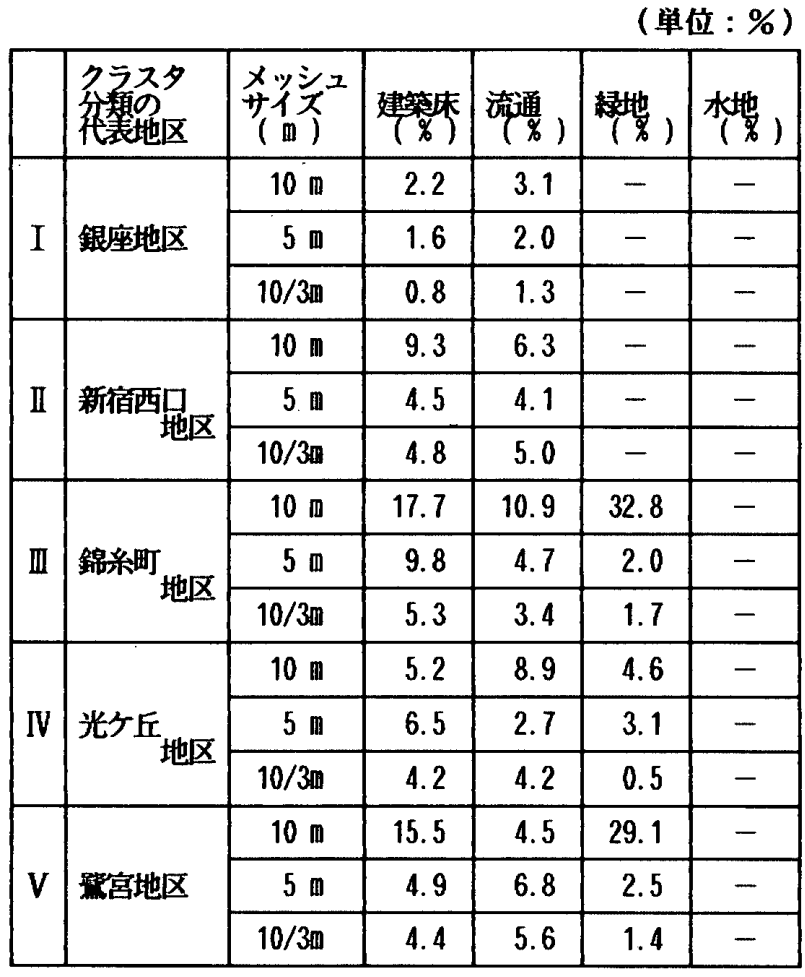

用途のメッシュマップを作成した。1メッシュ内に空間 用途が混在している場合は, 目視により1メッシュ内で 最大面積を占める空間用途をそのメッシュの空間用途に 同定した。次に，空間用途別にメッシュ数をカウントし た結果に 1 メッシュの面積 $\left(100 \mathrm{~m}^{2}, 25 \mathrm{~m}^{2}, 100 / 9 \mathrm{~m}^{2}\right)$ を乗じて空間用途別面積（これを「方式 1 による面積」 と称する) を算定した。

一方メッシュを用いずに，1/1000 地形図上におい て $1 \mathrm{~mm}$ 精度で空間用途別の面積（これを「方式 2 によ る面積」と称する）を算定した。両者の計測方法による 面積から下記の式によって誤差割合を算定した。誤差割 合を地区ごとに平均した結果を Table 1 に示す。

誤差割合 $(\%)=\left|\frac{\text { 方式 1による面積一方式 } 2 \text { による面積 }}{\text { 方式 } 2 \text { による面積 }}\right| \times 100$

Table 1 によれば, 特に, 10mメッシュを用いると， 錦糸町地区, 鴊宮地区では流通, 緑地, 建築床用途の面 積の誤差割合が大きい。これは, 両地区の道路幅員と建 物の建築面積がメッシュサイズよりかなり小さいものが 多く, 空間用途の同定の際に, 道路, 緑地, 建物が消去

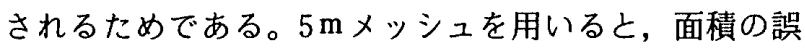
差割合の平均値を $10 \%$ 以内に抑えることができる。

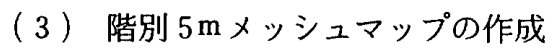

前述の空間の属性・用途の分類に従って銀座地区，錦 系町地区，䉆宮地区の 3 地区を対象として，空間の属性 と用途を階別に調查した。

調査に当たっては，建築物の階別の社名・店名が表示 
Table 2 The rate of total floor area of space attribute and space use to the size of a district <Ginza area>

\begin{tabular}{|c|c|c|c|c|c|c|c|}
\hline \multirow{2}{*}{\multicolumn{2}{|c|}{ 属 }} & \multirow[t]{2}{*}{ 性 } & \multicolumn{5}{|c|}{ 用 } \\
\hline & & & 建策林 & 流 通 & 緑 地 & 水 地 & void \\
\hline \multirow{4}{*}{ 公 } & \multirow[t]{2}{*}{ 公.上 } & 公·上.外 & 0 & 37 & 5 & 0 & 378 \\
\hline & & 公.上.内 & 0 & 0 & 0 & 0 & 0 \\
\hline & \multirow[t]{2}{*}{ 公.下 } & 公.下.外 & 0 & 0 & 0 & 0 & 0 \\
\hline & & 公.下.内 & 4 & 5 & 0 & 0 & 0 \\
\hline \multirow{4}{*}{ 私 } & \multirow[t]{2}{*}{ 私.上 } & 私-上·外 & 0 & 3 & 1 & 0 & 204 \\
\hline & & 私.上.内 & 372 & 0 & 0 & 0 & 0 \\
\hline & \multirow[t]{2}{*}{ 私・下 } & 私·下.外 & 0 & 0 & 0 & 0 & 0 \\
\hline & & 私・下.内 & 65 & 0 & 0 & 0 & 0 \\
\hline \multicolumn{3}{|c|}{. } & 441 & 45 & 6 & 0 & 582 \\
\hline
\end{tabular}

された住宅地図（1/1500）の他, 各種地図をもとに, 現地調査を行い，階別の空間用途の確認を行った。次に， 目視により 1 メッシュ内で最大面積を占める空間属性・ 用途をそのメッシュの空間属性・用途とすることによっ て, 空間属性・用途の $5 \mathrm{~m}$ メッシュマップを作成した。 この作業を階別に行った。

（4）空間属性・用途図の作成

次に，上記の階別のメッシュマップをもとに，空間属 性・用途別にメッシュ数をカウントした結果に 1 メッ シュの面積 $\left(25 \mathrm{~m}^{2}\right)$ を乗じて, 空間属性・用途別延べ 面積を算定した。

この結果を，地区別に集計したものが Table 2, Table 3, Table 4 である。これらの表には空間用途の 1 次分類を用いている。
Table 3 The rate of total floor area of space attribute and space use to the size of a district < Kinshichou area>

\begin{tabular}{|c|c|c|c|c|c|c|c|}
\hline & \multirow[t]{2}{*}{ 属 } & \multirow[t]{2}{*}{ 性 } & \multicolumn{5}{|c|}{ 用 } \\
\hline & & & 建第床 & 流 通 & 緑 地 & 水 地 & void \\
\hline \multirow{4}{*}{ 公 } & \multirow[t]{2}{*}{ 公.上 } & 公.上.外 & 0 & 35 & 2 & 0 & 333 \\
\hline & & 公.上.内 & 0 & 0 & 0 & 0 & 0 \\
\hline & \multirow[t]{2}{*}{ 公.下 } & 公·下.外 & 0 & 0 & 0 & 0 & 0 \\
\hline & & 公.下.内 & 0 & 0 & 0 & 0 & 0 \\
\hline \multirow{4}{*}{ 私 } & \multirow[t]{2}{*}{ 私.上 } & 私·上·外 & 0 & 3 & 15 & 0 & 496 \\
\hline & & 私.上.内 & 116 & 0 & 0 & 0 & 0 \\
\hline & \multirow[t]{2}{*}{ 私.下 } & 私一下.外 & 0 & 0 & 0 & 0 & 0 \\
\hline & & 私.下.内 & 1 & 0 & 0 & 0 & 0 \\
\hline & & & 117 & 38 & 17 & 0 & 829 \\
\hline
\end{tabular}

Table 4 The rate of total floor area of space attribute and space use to the size of a district < Saginomiya area $>$

(单位: \%)

\begin{tabular}{|c|c|c|c|c|c|c|c|}
\hline & 属 & 性 & & f & 月 & & \\
\hline & & & 建築床 & 流 通 & 緑 地 & 水 地 & void \\
\hline & 公·上 & 公.上.外 & 0 & 21 & 1 & 0 & 198 \\
\hline 公 & & 公.上.内 & 0 & 0 & 0 & 0 & 0 \\
\hline & 公·下 & 公.下.外 & 0 & 0 & 0 & 0 & 0 \\
\hline & & 公.下.内 & 0 & 0 & 0 & 0 & 0 \\
\hline & 私.上 & 私.上.外 & 0 & 2 & 48 & 1 & 672 \\
\hline 私 & & 私.上.内 & 57 & 0 & 0 & 0 & 0 \\
\hline & 私・下 & 私·下.外 & 0 & 0 & 0 & 0 & 0 \\
\hline & & 私·下.内 & 1 & 0 & 0 & 0 & 0 \\
\hline & & $\cdot$ & 58 & 23 & 49 & 1 & 870 \\
\hline
\end{tabular}

「void」は，空間領域を地表面 から地上10階までとして算定

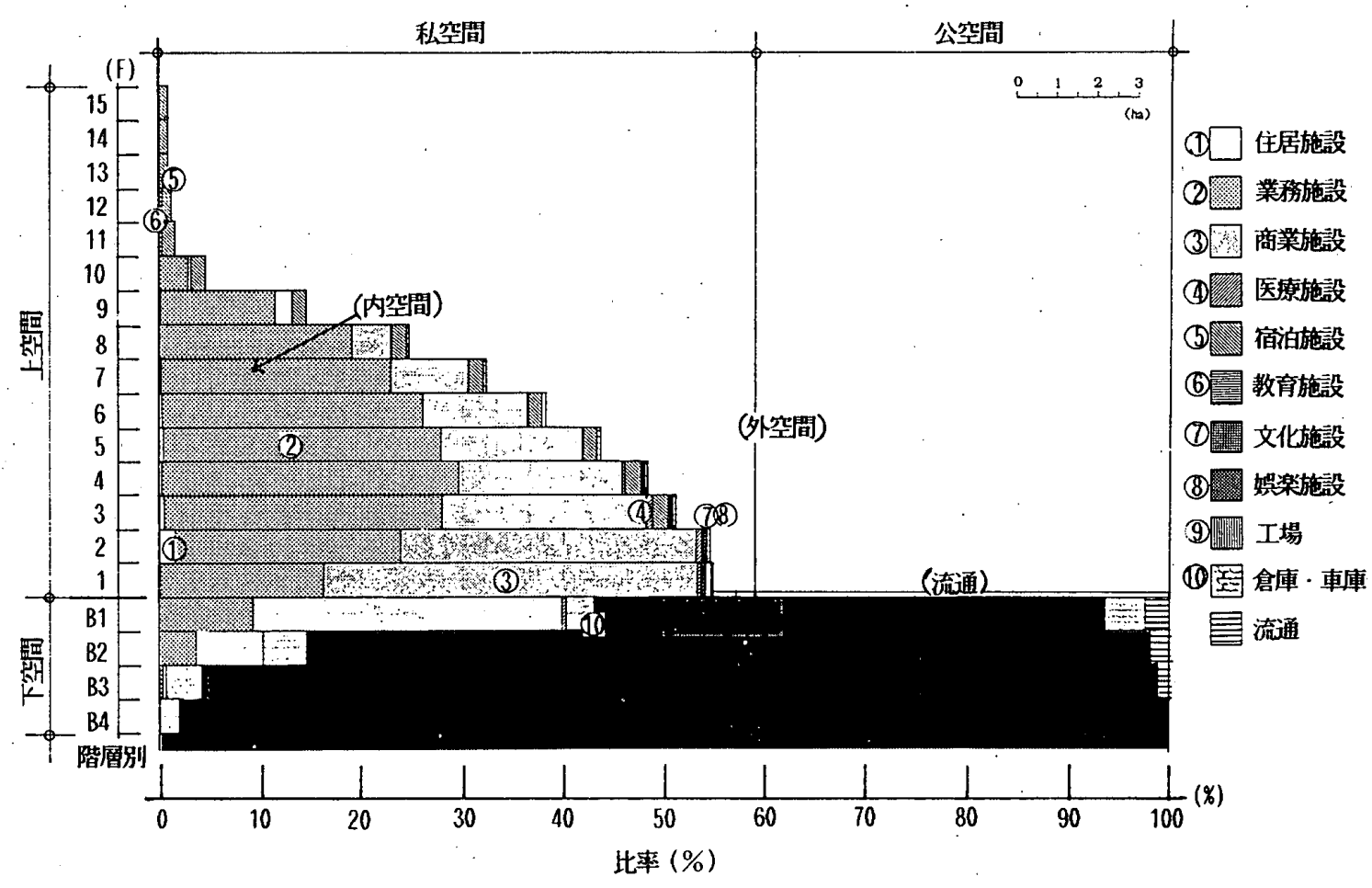

Fig. 7 Chart of space attribute and space use in Ginza area $(500 \mathrm{~m} \times 500 \mathrm{~m})$ 


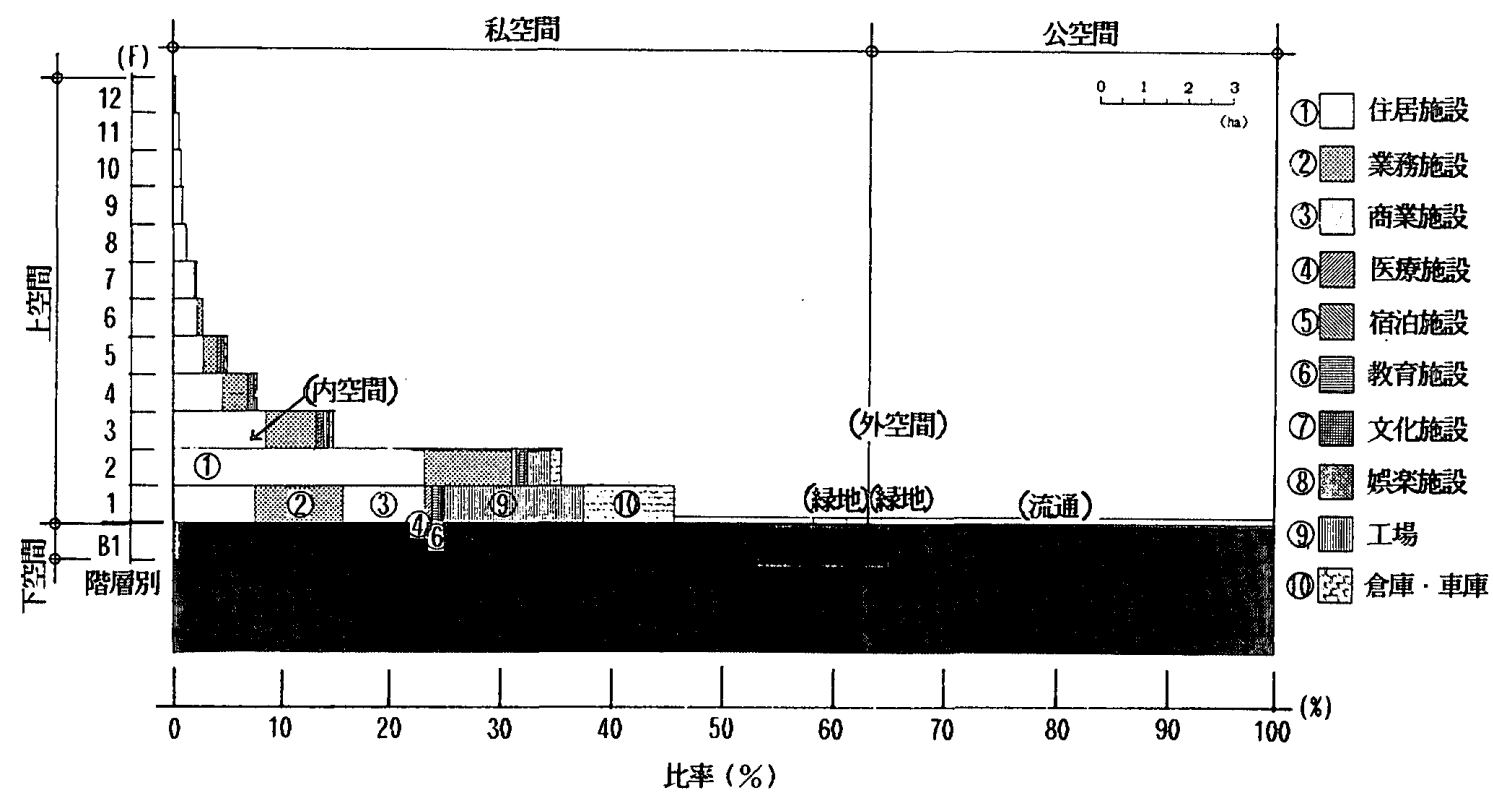

Fig. 8 Chart of space attribute and space use in Kinshichou area $(500 \mathrm{~m} \times 500 \mathrm{~m})$

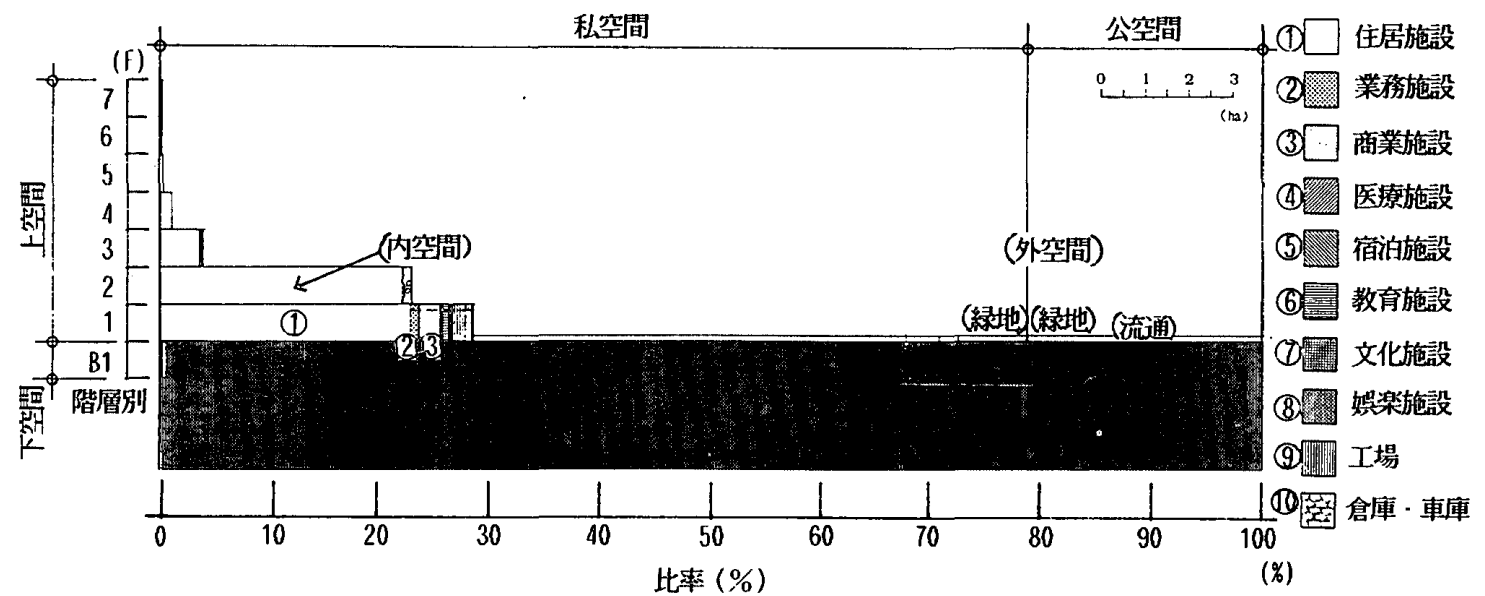

Fig. 9 Chart of space attribute and space use in Saginomiya area $(500 \mathrm{~m} \times 500 \mathrm{~m})$

また，横軸に空間属性・用途別の延べ面積，縦軸に階 をとって図化したものを「空間属性・用途図」と名付け た。各地区の空間属性・用途図を Fig. 7, Fig. 8, Fig. 9 に示す。これらの図には空間用途の 2 次分類を用 いているので階別の空間用途の現況がわかる。これらの 図表を用いて，各地区の空間属性・用途の比較を行う。

\section{3 地区の比䩙}

(1) 指標の検討

各地区の空間属性・用途別の延心面積を比較するにあ たって，指標の検討を行った。

都市における自然資本として，太陽光があたり，風が 通り，緑をはぐくむ地表面こそ重要であり，地表面の面 積（=地区面積）は空間管理の基礎となる面積である。 よって,ここでは地区面積 $\left(250000 \mathrm{~m}^{2}\right)$ に対する空間 属性・用途別延べ面積の比率（\%）を空間利用の指標之 して用いることとし, Table 2, Table 3, Table 4 には, この比率を記入した。このとき, 空間用途の 1 次分類項 目のうち「建築床」の延べ面積の, 地区面積に対する比
率（\%）はグロス容積率の定義と等しい。

（2）空間属性・用途 (1 次分類) の比較

Table 2, Table 3, Table 4 を用いて, 各地区の空間 属性・用途別の延べ面積を比較する。

イ. 各属性空間の機能分担について

建築床用途の私・上・内空間が人間活動の場の中心を なすが,この空間の環境・機能は私・上・外空間により 維持される。そして,この私・上・内空間と私・上・外 空間を合わせた私・上空間の環境・機能は，その直下に 広がる私・下空間により維持される。さらに，この私・ 上空間と私・下空間を合わせた私空間の環境・機能が公 空間により維持される。いわば，地区全体における公空 間と私空間，私空間における下空間と上空間，上空間に おける外空間と内空間の機能分担によって都市空間の環 境と機能が維持されるわけである。

.ロ. 私空間について

(1)私・上空間について

はじめに, Table 2, Table 3, Table 4 における私・上・ 
内空間についてみると，その延べ面積は，地区面積に対 して，銀座地区で $372 \%$ ，錦糸町地区で $116 \%$ ，鹗宮地 区で $57 \%$ であり，銀座地区においては私・上・内空間 の密度が高く，この機能・環境維持のために，これを支 える私・上・外空間,私・下空間, 公空間をいかに計画・ 管理するかが重要である。この私・上・内空間の細かい 用途については後述する。また，私・上・外空間の地表 面レベルの面積は, 地区面積に対して, 銀座地区で $4 \%$, 錦系町地区で $18 \%$ と低いが，唒宮地区では $51 \%$ であ る。以上から，私・上空間における内空間の延べ面積と 外空間の地表面レベルの面積の比率は，銀座地区で 99 $: 1$, 錦系町地区で $87 ： 13$, 䉆宮地区で $53 ： 47$ となる。 この数字は私・上・外空間を地表面レベルの面積で算定 したものであるが，実際には，私・上空間における外空 間は，地表面や内空間の上部に無限に広がっている。 1970 年までの建築基準法では, $31 \mathrm{~m}$ という建築物の高 さ制限があったので，仮にこの数字を用いて，地表面レ ベルから地上 10 階レベル（高さ $31 \mathrm{~m}$ に相当）まで空間 領域を設定し，この領域内の私・上・外空間の延べ面積 を算定すると，その延べ面積は地区面積に対して，銀座 地区で $208 \%$ ，錦糸町地区で $514 \%$ ，䉆宮地区では 723 \%に達する。この数字を用いて, 同じく地表面レベル から地上 10 階レベルまでの空間領域の私・上空間にお ける内空間と外空間の延べ面積の比率は, 銀座地区で $64 ： 36$, 錦糸町地区で $18 ： 82$, 鷺宮地区で $7 ： 93$ となる。

(2)私・下空間について

一方，私・下・内空間の延べ面積は，地区面積に対し て，銀座地区で $65 \%$ であるが，錦糸町地区，鷺宮地区 ではほとんビ $1 \%$ であり, 銀座地区の特徵のひとつで ある。

\section{八. 公空間について}

以上に述べた私空間を支える公空間に着目する。地区 全体の空間は地表面レベルの道路境界線によって, 上空 から地下にわたって公空間と私空間に分割されている。 地表面レベルにおける公空間と私空間の面積の比率を比 較すると, 銀座地区で $42: 58$, 錦糸町地区で $37: 63$, 鷺宮地区で $22: 78$ である。

(1)公・上空間について

次に, 公空間の空間属性・用途をみると, 各地区とも 上・外空間が中心で,その用途は流通および緑地である。 地表面レベルにおける流通用途分の上・外空間の面積は 地区面積に対して，銀座地区で $37 \%$ ，錦糸町地区で 35 \%，鷘宮地区で $21 \%$ である。また，同じく地表面レべ ルにおける緑地用途分の上・外空間の面積は地区面積に 対して，銀座地区で $5 \%$ ，錦禾町地区で $2 \%$ ，踼宮地区 で $1 \%$ である。

(2)公・下空間について

銀座地区の公空間の特徴として，この地区にのみ下.
内空間がつくられていることであり，錦糸町地区・鴽宮 地区にはこの属性の空間がない。銀座地区におけるこの 公・下・内空間の用途は建築床および流通で, その延べ 面積は地区面積に対して，建築床用途分が $4 \%$, 流通用 途分が $5 \%$ となっている。

\section{二. 外空間の属性と用途について}

先に述べた私・上・外空間とここで述べた公・上・外 空間の地表面レベルの面積を合計すると，地区の地表面 レベルの外空間の面積となる。その結果, 地表面レベル の外空間の面積は地区面積に対して，銀座地区で $46 \%$, 錦糸町地区で $55 \%$ ，䉆宮地区で $73 \%$ となる。その空 間属性・用途は，銀座地区，錦系町地区では流通用途の 公空間が中心であるのに対し，䉆宮地区では緑地用途の 私空間がその 5 割以上を占めており, 外空間の属性と用 途の特徵が出ている。

（3）空間属性・用途 (2 次分類) の比較

Fig.7, Fig. 8, Fig. 9 を用いて, 各地区の空間属性・ 用途別の延べ面積を比較する。

私・上・内空間の用途を階別にみると，銀座地区では 商業施設と業務施設が大半を占め, 低層階ほど商業施設 の空間が多く，高層階ほど業務施設が多い。住居施設は 2 階レベルにわずかにみられるのみである。錦糸町地区 では，1階レベルに工場，倉庫， 2 階レベルに住居施設 が多く, 住工混在状況が現れている。堅宮地区の用途は 住居施設が主体である。

（4）住居施設用途に限定した容積率緩和の検討

空間属性・用途図を用いた検討の一例として,例えば, 10 階レベル（高さ $31 \mathrm{~m}$ ) 以上の私空間を，住居施設用 途に限定して利用する条件の立体的な用途管理と容積率 緩和を行った場合について考える。

銀座地区の空間属性・用途図（Fig.7）の私・上・内 空間の階別延べ面積を示す帯のうち，隣接する階の間に ある帯の差の部分は，その階の屋上面積を示すことにな る。10 階レベルでは地区面積に対して $10 \%, 11$ 階レベ ルでは地区面積に対して $3 \%$ の延べ面積が屋上空間と して残されていることになる。

よって，この空間に住宅を新たに建設すれば， 1 層の 住宅の場合で地区面積に対して $13 \% ， 2$ 層の住宅の場 合で $26 \%$ の延べ面積を確保できることがわかる。実際 には，屋上空間は冷却塔等の工作物で占められているの で，これらを他の属性の空間に収容するなど対策が必要 なことはいうまでもないが，その移設先の空間の検討も この空間属性・用途図によることができる。

\section{5. 結 論}

以上から得られた結論は下記のとおり。

1) 約 $500 \mathrm{~m} \times 500 \mathrm{~m}$ 程度の平面的広がりの，上空・ 地下を含めた 3 次元空間を対象に, 空間属性と空間用途 の分類に基づく階層別空間利用の調查・解析手法の検討 
を行った。これにより，都市機能の維持に必要な自然資 本・社会資本の導入等の検討が可能となる。また，大深 度地下開発の際にも，上・下空間の連結を検討する上で の基礎資料となる。

2）各調查対象地区を分割するメッシュサイズを $5 \mathrm{~m}$ 之設定するにあたって，メッシュサイズを変化させた場 合の面積の誤差割合に関する検討を行った。その結果， $5 \mathrm{~m}$ メッシュを用いると, 面積の誤差割合の平均値を 10 \% 以内に㧕えられることがわかった。

3）階別の空間属性・用途のメッシュマップをもと に，空間属性・用途別の延べ面積を算定した。その算定 結果を，横軸に延べ面積，縦軸に階をとって表胃した図 を, 空間属性・用途図と名付けた。この空間属性・用途 図によって，各地区における公空間・私空間，上空間・ 下空間，外空間・内空間の分割のされ方と空間用途の現 状が把握可能となった。

6. おわりに

本研究の調査および資料整理の全般にわたってご協力 を頂いた当時大学院生（現在電源開発株式会社）の中川 幸彦君, 当時大学院生（現在東京ガス株式会社）の樺山 豊久君に感謝の意を表します。

\section{本論文に関連のある既発表論文}

1）中川幸彦・王 世燁・ 三浦昌生・尾島俊雄：東京都市街 地居住空間の環境整備に関する研究，その 1 , メッシュ 法を用いた銀坐地区の空間量の定量化，日本建築学会大 会学術講演梗概集 (九州), pp. 27 28, 1989 年 10 月

2）樺山豊久.中川幸彦・王 世樺・三浦昌生・尾島俊雄 : 東京都市街地居住空間の環境整備に関する研究，その 2, $500 \mathrm{~m}$ 圈の断面形態とその開放性, 日本建築学会大会学術 講演梗概集 (九州)，pp. 29 30，1989 年 10 月

3）王世苹・三浦昌生・尾島俊雄：東京都市街地居住空間 の環境整備に関する研究，その 3 ，空間属性分類による 地区の比較, 日本建築学会大会学術講演梗概集 (九州), pp. $31 \sim 32,1989$ 年 10 月
参考文献

1）尾島俊雄：環境場設定の Space Modular Co-ordination Chart, その 1, 時空間分割表, 日本建築学会論文報告集, 第 319 号, pp. 84 - 89, 昭和 57 年 9 月

2）尾島俊雄：環境場設定の Space Modular Co-ordination Chart, その 2, 実用化への考察, 日本建築学会論文報告 集, 第 320 号, pp. 108 115, 昭和 57 年 10 月

3）青木義次：メッシュデー夕解析の一方法としての空間相

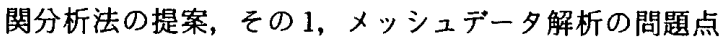
と空間相関分析法の理論, 日本建築学会計画系論文報告 集, 第 364 号, pp. 94 101, 昭和 61 年 6 月

4）青木義次：メッシュデー夕解析の一方法としての空間相 関分析法の提案, その 2, 土地利用の連担性 - 共存性 · 排斥性の計量化への応用, 日本建築学会計画系論文報告 集，第 368 号，pp. 119 125，昭和 61 年 10 月

5）青木義次：メッシュデー夕解析の一方法としての空間相 関分析法の提案, その3, 空間影響関数モデルの有効性 之問題点, 日本建築学会計画系論文報告集, 第 377 号, pp. $29-35$, 昭和 62 年 7 月

6）木島安史, 渡辺仁史：アーバンダイメンション，その 1 , 因子分析による地域分類の方法に関する研究, 日本建築 学会論文報告集, 第 197 号, pp. $51 \sim 57$, 昭和 47 年 7 月

7）本島安史, 渡辺仁史：アーバンダイメンション, その 2 ・ 重複集計によるメッシュアナリシス, 日本建築学会論文 報告集，第 198 号，pp. $37 \sim 43$, 昭和 47 年 8 月

8）鳴海邦碩：立地パターンと用途の立体的混在化，大阪市 都心地区マンション研究, その 2, 日本建築学会大会学 術講演梗概集 (東海), pp. 131 132, 昭和 60 年 10 月

9）八木澤壮一ほか 4 名：階別用途の構成之高度利用の試算, 既成市街地における土地及び建物の利用構造に関する研 究, その 8, 日本建築学会大会学術講演梗概集 (関東), pp. $2127 \sim 2128$, 昭和 59 年 10 月

10）都市計画教育研究会編：都市計画教科書：彰国社, 昭和 62 年 6 月

11）日本建築学会環境工学委員会：都心における居住空間の 設計，大会研究協議会資料，昭和 63 年 10 月 (1989 年 9 月 8 日原稿受理, 1989 年 12 月 28 日採用決定) 